\title{
KETAHANAN PANGAN RUMAH TANGGA PETANI ANGGOTA LUMBUNG DI KECAMATAN GADING REJO, KABUPATEN PRINGSEWU
}

\author{
(Food Security of Farmer Household of Granary Members in Gading Rejo Subdistrict, Pringsewu Regency) \\ Marita Infia Fitriani, Fembriarti Erry Prasmatiwi, Rabiatul Adawiyah
}

Jurusan Agribisnis, Fakultas Pertanian, Universitas Lampung, Jl. Prof. Dr. Soemantri Brojonegoro No. 1

Bandar Lampung 35141, e-mail: fembriarti.erry@fp.unila.ac.id

\begin{abstract}
This study aims to analyze food security level, the factors affecting food security, and the efforts to increase food security of farmer household of granary member. The location of this study is chosen purposively as consideration that the group of granaries received the granary development program in Gading Rejo Subdistrict, Pringsewu Regency with 44 farmers of granary members who are selected by proportional random sampling method. Data were collected in April 2018. Food security level is analyzed using cross classification between food expenditure and food sufficiency level, factors affecting the level of food security is analyzed using ordinal logistic regression, and the efforts to increase the level of food security is analyzed using descriptive qualitative analysis. The study shows that food security according to BPS category as much as $22 ., 73 \%$ is in secure category, $15.91 \%$ less secure, $34.09 \%$ vulnerable, and $27.27 \%$ insecure. Food security according to nutrition science and the 2012 Constitution of Food as much as $45.45 \%$ is in secure category, 27,27\% less secure, $15.91 \%$ vulnerable, and $11.36 \%$ insecure. Factors that influence the level of food security are rice production, price of rice, and side occupation. Efforts to increase food security are programs on increasing income through irrigation and crop indexes, improving nutrition through education on nutrition and food by the government, accelerating food diversification, and development of food barns. Farmer's effort to overcome food shortages is by changing habit in the quality of food consumed.
\end{abstract}

Key words: food security, granary member

\section{PENDAHULUAN}

Ketahanan pangan nasional/wilayah memiliki tiga subsistem yaitu subsistem ketersediaan, distribusi, dan konsumsi. Ketersediaan pangan merupakan kondisi tersedianya pangan dari hasil produksi dalam negeri dan cadangan pangan nasional serta impor apabila kedua sumber utama tidak dapat memenuhi kebutuhan. Distribusi berkaitan dengan aksesibilitas baik fisik maupun ekonomi serta intervensi pemerintah dalam distribusi pangan pokok. Subsistem konsumsi erat kaitannya dengan kualitas pangan yang dikonsumsi, dimana harus memiliki gizi yang seimbang, mutu dan keamanan harus terjamin, serta dilakukannya penganekaragaman pangan agar kebutuhan gizi tercukupi (Indriani 2015).

Ketersediaan pangan dilihat dengan tercukupinya kebutuhan pangan, khususnya pangan pokok. Pangan pokok sebagian besar masyarakat Indonesia adalah beras, pemenuhannya bergantung produksi petani padi. Menurut Dinas Ketahanan Pangan Kabupaten Pringsewu (2017), Kecamatan Gading Rejo memiliki luas panen dan produksi padi paling tinggi di Kabupaten Pringsewu. Luas panen Kecamatan Gading Rejo adalah 7.922 hektar dan produksi yang dihasilkan untuk dua musim tanam sebesar 42.866 ton. Tingginya produksi akan memengaruhi ketersediaan pangan di wilayah sampai tingkat rumah tangga. Terpenuhinya pangan di tingkat kecamatan diharapkan akan memenuhi ketersediaan pangan sampai di tingkat rumah tangga, sehingga akan tercapai ketahanan pangan yang baik bagi setiap rumah tangga di Kecamatan Gading Rejo.

Tingginya produksi padi di Kecamatan Gading Rejo belum diimbangi dengan kesejahteraan masyarakatnya. Menurut Badan Pusat Statistik Kabupaten Pringsewu (2017), Kecamatan Gading Rejo merupakan kecamatan yang memiliki angka paling tinggi untuk klasifikasi keluarga pra sejahtera yaitu sebanyak 3.114 keluarga. Pemenuhan energi di Kabupaten Pringsewu juga belum memenuhi standar. Rerata Pola Pangan Harapan (PPH) Kabupaten Pringsewu belum mencapai skor ideal, khususnya konsumsi energi di Kecamatan Gading Rejo yang hanya mencapai $1.572 \mathrm{kkal} / \mathrm{kap} / \mathrm{hari}$. Gading Rejo merupakan salah satu kecamatan yang mengikuti program pengembangan lumbung dari Dinas Ketahanan 
Pangan Kabupaten Pringsewu. Kegiatan ini memiliki tujuan meningkatkan stok pangan di lumbung sebagai cadangan pangan bagi anggotanya, terutama yang mengalami kerawanan pangan dengan indikator dampak yang diharapkan adalah tercukupinya kebutuhan pangan masyarakat sepanjang waktu. Pengembangan lumbung pangan masyarakat sangat erat kaitannya dengan subsistem ketersediaan yang mendukung ketahanan pangan dengan adanya akses dan kecukupan pangan dengan menyimpan cadangan pangan di tingkat rumah tangga. Menurut Darwanto dan Pranyoto (2006), beragamnya jenis pangan dan produksi pangan bergantung pada kondisi iklim, maka keberadaan lumbung pangan sebagai bagian dari kegiatan antisipasi terhadap bencana alam maupun serangan OPT menjadi semakin diperlukan.

Sulitnya pengairan menyebabkan petani hanya panen dua kali selama satu tahun. Petani harus memperkirakan seberapa banyak hasil panen yang disimpan untuk konsumsi setiap hari hingga menunggu panen berikutnya. Peran lumbung sangat penting sebagai penyimpanan saat masa tunggu panen, agar petani tidak mengalami kekurangan. Pengelolaan cadangan di Kabupaten Pringsewu belum terintegrasi dengan baik, karena beberapa lumbung saat masa tunggu panen belum memiliki cadangan pangan di lumbung untuk kebutuhan minimum konsumsi anggota. Petani belum sepenuhnya memiliki keinginan untuk menyimpan hasil panennya di lumbung, karena hanya bergantung pada gabah bantuan. Selain itu, petani cenderung menjual langsung hasil produksi setelah panen untuk memperoleh pendapatan. Padahal, manfaat yang diharapkan dari lumbung pangan adalah sebagai penyimpanan cadangan pangan saat terjadi rawan pangan, baik transien maupun kronis. Berdasarkan uraian tersebut, penelitian ini bertujuan untuk menganalisis tingkat ketahanan pangan, faktor yang memengaruhi ketahanan pangan, dan upaya untuk meningkatkan ketahanan pangan anggota lumbung.

\section{METODE PENELITIAN}

Metode yang digunakan pada penelitian ini adalah metode survei. Lokasi penelitian dipilih secara sengaja di Kecamatan Gading Rejo, Kabupaten Pringsewu dengan pertimbangan adanya lumbung yang mengikuti program pengembangan lumbung pangan yang dibina Dinas Ketahanan Pangan Kabupaten Pringsewu. Populasi penelitian sebanyak 103 rumah tangga petani padi dari empat kelompok lumbung yang ada di empat desa yaitu Desa Gading Rejo Utara, Bulukarto, Bulurejo dan
Wonosari. Pengambilan data dilakukan pada bulan April 2018.

Penentuan jumlah sampel menggunakan rumus perhitungan sampel Issac dan Michael dalam Sugiarto et al. (2003). Berdasarkan perhitungan, diperoleh sampel sebanyak 44 rumah tangga petani anggota lumbung. Responden penelitian ini adalah kepala keluarga petani anggota lumbung. Jumlah sampel untuk setiap desa ditentukan dengan metode proportional random sampling. Penarikan sampel rumah tangga di setiap desa ditentukan dengan metode simple random sampling. Pengumpulan data konsumsi menggunakan metode recall melalui wawancara menggunakan kuesioner yang dilakukan berulang dengan hari yang berbeda.

Tingkat ketahanan pangan dianalisis menggunakan indikator Jonsson and Toole (1991) dalam Maxwell et al. (2000) dengan menggunakan klasifikasi silang pangsa pengeluaran dan konsumsi energi. Perhitungan Pangsa Pengeluaran Pangan (PPP) pada berbagai kondisi dan berbagai kelompok pendapatan menggunakan rumus sebagai berikut :

$\mathrm{PPP}=\frac{\mathrm{FE}}{\mathrm{TE}} \times 100 \%$

Keterangan:

$\mathrm{PPP}=$ Pangsa pengeluaran pangan $(\%)$

$\mathrm{FE}=$ Pengeluaran untuk belanja pangan (Rp/bulan)

$\mathrm{TE}=$ Total pengeluaran $(\mathrm{Rp} / \mathrm{bulan})$

Perhitungan Angka Kecukupan Energi (AKE) dihitung berdasarkan berat badan menurut kelompok umur dan jenis kelamin.

$\mathrm{AKE}=\frac{\mathrm{BB} \text { aktual }}{\mathrm{BB} \text { standar }} \mathrm{x}$ AKE dalam tabel

Keterangan:

AKE = Angka kecukupan energi (kkal)

BB Aktual = Berat badan aktual $(\mathrm{kg})$

BB Standar = Berat badan standar $(\mathrm{kg})$

Tingkat kecukupan energi dapat dihitung setelah informasi konsumsi energi diperoleh dan angka kecukupan energi yang seharusnya dipenuhi rumah tangga diketahui.

$\mathrm{TKE}=\frac{\text { Konsumsi riil }}{\mathrm{AKE}} \times 100 \%$ 
Tabel 1. Tingkat ketahanan pangan rumah tangga

\begin{tabular}{ccc}
\hline Konsumsi energi & \multicolumn{2}{c}{ Pangsa pengeluaran pangan } \\
\cline { 2 - 3 } per unit ekuivalen & Rendah & Tinggi \\
dewasa & $(<60 \%$ PPP $)$ & $(\geq 60 \%$ PPP $)$ \\
\hline Cukup & Tahan & Rentan \\
$(>80 \%$ AKG $)$ & pangan & pangan \\
Kurang & Kurang & Rawan \\
$(\leq 80 \%$ AKG $)$ & pangan & pangan \\
\hline
\end{tabular}

Keterangan:

$\begin{array}{ll}\text { TKE } & =\text { Tingkat kecukupan energi (\%) } \\ \text { Konsumsi riil } & =\text { Konsumsi energi riil (kkal) } \\ \text { AKE } & =\text { Angka kecukupan energi (kkal) }\end{array}$

Faktor yang memengaruhi ketahanan pangan di analisis menggunakan model logistik ordinal dengan persamaan berikut:

$$
\begin{aligned}
\mathrm{Pi}=\ln \left[\frac{\mathrm{Pi}}{1-\mathrm{Pi}}\right]=\mathrm{Zi}= & \alpha+\beta_{1} \mathrm{X}_{1}+\beta_{2} \mathrm{X}_{2}+\beta_{3} \mathrm{X}_{3}+ \\
& \beta_{4} \mathrm{X}_{4}+\beta_{5} \mathrm{X}_{5}+\beta_{6} \mathrm{X}_{6}+\beta_{7} \mathrm{X}_{7} \\
& +\mathrm{D}+\mu \ldots \ldots \ldots \ldots \ldots \ldots \ldots \ldots \ldots \ldots
\end{aligned}
$$

Keterangan:

$\mathrm{Zi} \quad=$ Probabilitas $\mathrm{Z}_{1}=\mathrm{Z}(\mathrm{Y}=4)$ untuk rumah tangga tahan pangan, probabilitas $\mathrm{Z}_{2}=\mathrm{Z}$ $(Y=3)$ untuk rumah tangga kurang pangan, probabilitas $\mathrm{Z}_{3}=\mathrm{Z}(\mathrm{Y}=2)$ untuk rumah tangga rentan pangan, probabilitas $\mathrm{Z}_{4}=\mathrm{Z}(\mathrm{Y}=1)$ untuk rumah tangga rawan pangan

$\mathrm{Pi} \quad=$ Peluang anggota lumbung untuk menentukan tingkat ketahanan pangan bila Xi diketahui

$\mathrm{X} 1=$ Pendidikan kepala keluarga (tahun)

$\mathrm{X} 2=$ Pendidikan ibu rumah tangga (tahun)

$\mathrm{X} 3=$ Besar anggota rumah tangga (orang)

$\mathrm{X} 4=$ Produksi padi $(\mathrm{Kg})$

$\mathrm{X} 5 \quad=$ Pendapatan rumah tangga (Rp/bulan)

$\mathrm{X} 6=$ Harga beras $(\mathrm{Rp})$

$\mathrm{X} 7 \quad=$ Harga minyak goreng $(\mathrm{Rp})$

Dummy $=$ Pekerjaan sampingan (punya pekerjaan sampingan (1) dan tidak mempunyai pekerjaan sampingan (0))

Estimasi model logit menggunakan uji Likelihood Ratio (LR) untuk mengetahui tingkat pengaruh seluruh variabel independen secara bersama-sama terhadap variabel dependen. Uji Wald dilakukan untuk menguji pengaruh secara individu variabel independen terhadap variabel dependen.

Upaya peningkatan ketahanan pangan dianalisis menggunakan analisis deskriptif kualitatif dengan menelaah upaya yang dilakukan oleh Pemerintah
Daerah dan partisipasi petani untuk meningkatkan ketahanan pangan. Upaya peningkatan ketahanan pangan dianalisis berdasarkan subsistem ketahanan pangan yaitu ketersediaan, distribusi, dan konsumsi.

\section{HASIL DAN PEMBAHASAN}

\section{Gambaran Umum Lumbung di Kecamatan Gading Rejo}

Lumbung pangan di Kecamatan Gading Rejo yang menjadi objek penelitian yaitu lumbung pangan Sidomuncul, Karya Tani, Pancasari 2 dan Rukun Utama 2. Keempat lumbung pangan merupakan lumbung yang dimiliki kelompok tani. Lumbung pangan Pancasari 2 merupakan jenis lumbung bantuan dan lainnya swadaya. Kegiatan lumbung di lokasi penelitian yaitu simpan pinjam gabah, simpan pinjam pupuk, penjualan benih, penangkaran benih, peminjaman saprodi, penyediaan gabah sebagai cadangan lumbung, pengelolaan lahan sawah, kolam dan kebun kelompok, penggilingan padi serta kios tani. Kegiatan lumbung tersebut sejalan dengan penelitian Ramadhani et al. (2018) bahwa lumbung juga merupakan modal sosial untuk meningkatkan usahatani melalui penyediaan pinjaman pupuk dan modal usahatani. Pupuk yang disediakan oleh lumbung pangan yaitu Urea, NPK, SP36 dan TSP.

Penyimpanan gabah pada lumbung pangan dilakukan setelah musim panen. Pembongkaran dilakukan saat anggota akan mengolah lahan, supaya pinjaman gabah yang diberikan pada anggota dapat digunakan untuk kebutuhan konsumsi rumah tangga selama masa tunggu panen atau dapat dijual untuk kebutuhan membeli sarana produksi usahatani. Lumbung pangan berperan sebagai suatu sistem penyangga harga gabah, karena dapat mengantisipasi fluktuasi harga bahan pangan, agar tidak terlalu rendah pada saat musim panen dan tidak terlalu tinggi pada saat musim paceklik (Darwanto dan Pranyoto 2006).

Keempat lumbung memperoleh bantuan pengisian lumbung dari kegiatan pengembangan lumbung Dinas Ketahanan Pangan Kabupaten Pringsewu. Bantuan yang diberikan adalah uang sebesar Rp5.000.000,00 yang dibelikan gabah sebanyak satu ton, bangunan lumbung dan lantai jemur, serta peralatan lumbung. Kelompok pada tahap ini sudah dibina dan memiliki kemantapan dalam kelembagaan serta penguatan cadangan pangan. 


\section{Profil Responden Anggota Lumbung}

Kepala keluarga dan istri berada pada usia produktif yaitu 44-60 tahun dengan rata-rata usia 49 tahun untuk kepala rumah tangga, sedangkan rata-rata usia ibu rumah tangga 47 tahun. Keadaan ini dapat menunjang peningkatan produksi usahatani dan memperbaiki gizi keluarga, karena dengan umur yang masih produktif petani lebih peka dan mudah mengadopsi suatu pengetahuan baru untuk meningkatkan pengetahuan dan keterampilan. Tingkat pendidikan tertinggi kepala keluarga dan istri yaitu berada pada jenjang SMA sebanyak 38,64 persen dan 34,09 persen. Anggota lumbung telah menyadari bahwa pendidikan penting, karena adanya kemantapan pola pikir yang lebih matang untuk mengambil keputusan, terutama saat berusahatani. Jumlah anggota keluarga petani di Kecamatan Gading Rejo lebih banyak pada kisaran 3-4 orang sebanyak 61,36 persen dan rata-rata jumlah anggota keluarga 4 orang.

Luas lahan anggota lumbung minimum 0,20 dan maksimum 1,75 hektar dengan rata-rata luas lahan 0,53 hektar. Status lahan anggota lumbung 95,45 persen adalah milik sendiri dan 4,55 persen petani yang melakukan usahatani dengan menyewa lahan. Total produksi dari hasil usahatani yang diperoleh sebanyak $6.435 \mathrm{~kg}$ dalam satu tahun atau dua kali musim tanam. Hasil produksi yang dijual oleh petani adalah sebesar 93,62 persen, konsumsi sebesar 5,66 persen, lainnya digunakan untuk arisan dan benih. Penelitian ini searah dengan Mariyani et al. (2017) yang mengatakan bahwa petani padi menggunakan hasil panen untuk berbagai macam kegiatan seperti untuk konsumsi rumah tangga, dijual, kegiatan sosial dan agama, serta digunakan untuk iuran lumbung. Sebagian besar hasil panen gabah untuk dijual. Anggota lumbung yang bekerja sebagai petani sangat dominan yaitu sebanyak 95,46 persen, lainnya bekerja sebagai pegawai dan pedagang alat bangunan. Pendapatan rumah tangga diperoleh oleh petani baik dari kegiatan on farm, off farm, dan non farm. Pendapatan anggota lumbung berkisar Rp1.122.583,33 - Rp4.366.069,44/bulan.

\section{Tingkat Ketahanan Pangan Anggota Lumbung}

\section{Ketersediaan dan Pangsa Pengeluaran Pangan}

Ketersediaan pangan pokok diperoleh dari produksi sendiri yang disisihkan setiap panen untuk kebutuhan konsumsi. Jumlah produksi padi yang diperoleh dari hasil panen sendiri 6.435 $\mathrm{kg} / \mathrm{tahun}$ dan dari pinjaman lumbung 218,57 $\mathrm{kg} /$ tahun. Ketersediaaan pangan yang digunakan untuk konsumsi sebesar 5,66 persen atau sebanyak $364,32 \mathrm{~kg} /$ tahun. Kekurangan cadangan pangan beras lebih mudah teratasi, karena adanya kelembagaan lumbung di tengah petani. Lumbung akan meminjamkan gabah untuk anggotanya demi ketersediaan rumah tangga. Hal tersebut didukung oleh penelitian Ramadhani et al. (2018), anggota lumbung memanfaatkan lumbung dengan cara melakukan pinjaman setiap tahun. Pinjaman dapat berupa gabah, uang, beras dan pupuk, dimana pinjaman gabah dibatasi antara $100-500 \mathrm{~kg}$ per musim.

Pangsa pengeluaran pangan dianalisis berdasarkan kriteria BPS serta pengelompokan bahan pangan dalam Pola Pangan Harapan (PPH) dan Undangundang Pangan Tahun 2012. Komponen yang dianalisis sama hanya berbeda pada penempatan pengeluaran rokok. Persentase total pengeluaran pangan untuk kategori BPS lebih besar, karena adanya rokok. Hal ini didukung oleh penelitian Sugesti et al. (2015), besarnya pengeluaran rokok melebihi besarnya pengeluaran untuk sayur sayuran, buah, susu atau pangan yang bergizi lainnya. Rumah tangga dapat mengurangi konsumsi rokok, karena tidak adanya zat gizi yang terdapat pada rokok dan dapat menimbulkan berbagai penyakit bagi tubuh.

Pangsa pengeluaran pangan menurut BPS sebesar 61,84 persen, sedangkan menurut PPH dan UU Pangan sebesar 55,33 persen terhadap total pengeluaran. Rumah tangga dengan pangsa pengeluaran pangan rendah menurut BPS sebesar 34,09 persen dan sebanyak 65,91 persen rumah tangga memiliki pangsa pengeluaran tinggi

Tabel 2. Pengeluaran pangan rumah tangga per bulan menurut PPH dan UU Pangan di Kecamatan Gading Rejo

\begin{tabular}{lrr}
\hline \multicolumn{1}{c}{ Jenis Pengeluaran } & Rata-rata $(\mathrm{Rp})$ & Persentase \\
\hline Bahan pangan pokok & $285.625,00$ & 13,16 \\
Lauk pauk & $304.460,23$ & 14,03 \\
Kacang-kacangan & $48.312,50$ & 2,23 \\
Sayuran & $100.011,36$ & 4,61 \\
Buah-buahan & $98.215,91$ & 4,52 \\
Sumber lemak & $49.193,18$ & 2,27 \\
Makanan/jajanan & $129.147,73$ & 5,95 \\
Minuman & $87.295,45$ & 4,02 \\
Bumbu & $98.681,82$ & 4,55 \\
Total Pengeluaran & $1.200 .943,18$ & 55,33 \\
Pangan & & \\
\hline
\end{tabular}


Tabel 3. Pengeluaran nonpangan rumah tangga per bulan menurut PPH dan UU Pangan di Kecamatan Gading Rejo

\begin{tabular}{lrr}
\hline Jenis Pengeluaran & \multicolumn{1}{c}{ Rata-rata (Rp) } & Persentase \\
\hline Rokok & $141.545,45$ & 6,52 \\
Bahan bakar & $141.006,98$ & 6,50 \\
Listrik dan air & $150.002,33$ & 6,91 \\
Pendidikan & $53.023,26$ & 2,44 \\
Kesehatan & $8.744,19$ & 0,40 \\
Pakaian & $26.096,23$ & 1,20 \\
Komunikasi & $86.627,91$ & 3,99 \\
Pajak & $25.343,99$ & 1,17 \\
Keperluan mandi dan & $201.586,05$ & 9,29 \\
kecantikan & $6.162,79$ & 0,28 \\
Sosial & $11.162,79$ & 0,51 \\
Rekreasi & $118.372,09$ & 5,45 \\
Keperluan lainnya & $969.674,05$ & 44,67 \\
\hline Total Pengeluaran & $2.170 .617,23$ & 100,00 \\
Non Pangan &
\end{tabular}

Persentase rumah tangga yang memiliki pangsa pengeluaran rendah menurut PPH dan UU Pangan sebanyak 63,64 persen dan rumah tangga dengan kriteria pangsa pengeluaran tinggi yang sebanyak 36,36 persen. Pangsa pengeluaran pangan tinggi mencerminkan pendapatan rumah tangga yang rendah, sehingga rumah tangga lebih banyak mengalokasikan pendapatannya untuk membeli kebutuhan pangan sebagai kebutuhan primer, sehingga pendapatan belum terdistribusi dengan baik untuk memenuhi kebutuhan pangan dan non pangan, karena rendahnya pendapatan. Searah dengan penelitian Hernanda et al. (2013), besarnya pengeluaran pangan berbanding terbalik dengan besarnya pendapatan rumah tangga, semakin besar pangsa pengeluaran pangan maka hal ini mencerminkan rendahnya pendapatan rumah tangga petani.

\section{Subsistem Distribusi (akses) Pangan}

Akses ekonomi dilihat dari pendapatan rumah tangga dan harga bahan pangan. Pendapatan cukup untuk memenuhi kebutuhan pangan dan non pangan, rumah tangga yang belum mampu memenuhi salah satu kebutuhan akan mencari pekerjaan sampingan ataupun mengurangi pembelian lauk-pauk. Harga pangan di daerah penelitian juga tergolong stabil dan terjangkau oleh rumah tangga. Harga pangan di setiap desa yang diteliti tidak terlalu jauh berbeda, karena rumah tangga dapat mengakses pangan dengan mudah di setiap warung maupun pasar tradisional.
Tabel 4. Pangsa pengeluaran pangan rumah tangga di Kecamatan Gading Rejo menurut BPS, PPH dan UU Pangan

\begin{tabular}{|c|c|c|c|c|}
\hline \multirow{2}{*}{$\begin{array}{l}\text { Kriteria } \\
\text { PPP }\end{array}$} & \multicolumn{2}{|c|}{ BPS } & \multicolumn{2}{|c|}{$\begin{array}{l}\text { PPH dan UU Pangan } \\
2012 \\
\end{array}$} \\
\hline & $\begin{array}{l}\text { Jumlah } \\
(\mathrm{n})\end{array}$ & $(\%)$ & $\begin{array}{l}\text { Jumlah } \\
\text { (n) }\end{array}$ & $(\%)$ \\
\hline Rendah & 15 & 34,09 & 28 & 63,64 \\
\hline Tinggi & 25 & 65,91 & 16 & 36,36 \\
\hline Jumlah & 44 & 100,00 & 44 & 100,00 \\
\hline
\end{tabular}

Akses fisik meliputi sarana dan prasarana perhubungan (letak pasar), dan infrastruktur pedesaan (jalan). Rumah tangga di Desa Wonosari dan Gading Rejo Utara lebih memilih pergi ke pasar Gading Rejo, karena dekat dengan rumah dimana jarak yang ditempuh hanya $1,5 \mathrm{~km}$. Rumah tangga yang tinggal di Desa Bulu Rejo memiliki pasar desa yang buka setiap hari selasa dan jumat dengan jarak tempuh $500 \mathrm{~m}$. Rumah tangga di Desa Bulukarto lebih dekat pergi ke pasar terminal Pringsewu yang hanya berjarak 2,50 $\mathrm{km}$. Akses jalan sangat mudah, karena melewati jalan raya utama dan jalan desa yang semuanya sudah di aspal.

\section{Konsumsi dan Angka Kecukupan Energi}

Rata-rata konsumsi energi riil rumah tangga anggota lumbung sebesar 8.443,00 kkal. Rumah tangga mampu mencukupi kebutuhan energi, karena angka kecukupan energi yang dianjurkan untuk setiap rumah tangga sebesar 9.130,23 kkal, dengan tingkat tingkat kecukupan energi yang diperoleh rumah tangga sebesar 92,47 persen. Kontribusi energi terbesar disumbangkan oleh golongan padi-padian yaitu sebesar 46,34 persen, akan tetapi belum mencukupi komposisi energi yang seharusnya yaitu 50,00 persen.

Kecukupan protein riil di tingkat rumah tangga sebesar 244,51 gram, sudah melebihi angka kecukupan protein yang dianjurkan yaitu sebesar 233,96 gram. Hal ini menunjukkan bahwa rumah tangga telah mampu memenuhi protein yang dibutuhkan oleh tubuh. Pangan hewani yang sering dikonsumsi oleh petani di antaranya telur, ayam, ikan, dan susu. Bahan pangan tersebut merupakan pangan hewani yang kaya akan protein mengandung asam amino esensial bagi tubuh.

Anggota lumbung di Kecamatan Gading Rejo sebanyak 61,36 persen memiliki TKE yang cukup. Anggota lumbung dengan tingkat kecukupan energi kurang hanya sebanyak 38,64 persen. 
Tabel 5. Rata-rata konsumsi energi dan protein petani anggota lumbung menurut golongan pangan

\begin{tabular}{lrr}
\hline \multicolumn{1}{c}{ Golongan pangan } & $\begin{array}{c}\text { Konsumsi } \\
\text { energi (kkal) } \\
\text { per rumah } \\
\text { tangga }\end{array}$ & $\begin{array}{c}\text { Kontribusi } \\
\text { terhadap } \\
\text { total } \\
\text { konsumsi } \\
(\%)\end{array}$ \\
\hline Padi-padian & $3.912,55$ & 46,34 \\
Umbi-umbian & 976,36 & 11,56 \\
Kacang-kacangan & 776,41 & 9,20 \\
Sayur dan buah & 566,27 & 6,71 \\
Pangan hewani & $1.144,38$ & 13,55 \\
Lemak dan minyak & 599,65 & 7,10 \\
Buah biji berminyak & 281,66 & 3,34 \\
Gula & 123,96 & 1,47 \\
Lain-lain & 61,77 & 0,73 \\
\hline Konsumsi energi (Kkal) & $8.443,00$ & 100,00 \\
AKE & $9.130,23$ & \\
Konsumsi protein (gr) & 244,51 & \\
AKP & 233,96 & \\
\hline
\end{tabular}

Konsumsi energi yang rendah disebabkan oleh faktor kebiasaan dalam menyediakan bahan pangan dan belum mengarah pada anjuran beragam, bergizi, seimbang dan aman. Rumah tangga hanya mampu membeli bahan pangan yang tersedia di warung ataupun pasar tanpa memahami kebutuhan energi tubuh. Penelitian ini sejalan dengan Hernanda et al. (2017) yang menyatakan bahwa rendahnya konsumsi energi dan protein rumah tangga petani disebabkan oleh faktor kebiasaan, baik dari kebiasaan makan maupun kebiasaan menyediakan bahan pangan.

Tabel 6. Tingkat kecukupan energi anggota lumbung di Kecamatan Gading Rejo

\begin{tabular}{ccrr}
\hline $\begin{array}{c}\text { Tingkat Kecukupan } \\
\text { Energi }\end{array}$ & $\begin{array}{c}\text { Kriteria } \\
\text { TKE }\end{array}$ & $\begin{array}{c}\text { Jumlah } \\
\text { (n) }\end{array}$ & $(\%)$ \\
\hline$>80 \%$ & Cukup & 27 & 61,36 \\
$\leq 80 \%$ & Kurang & 17 & 38,64 \\
\hline Jumlah & & 44 & 100,00 \\
\hline
\end{tabular}

Tabel 7. Sebaran rumah tangga anggota lumbung berdasarkan tingkat ketahanan pangan

\begin{tabular}{|c|c|c|c|c|}
\hline \multirow{2}{*}{$\begin{array}{l}\text { Tingkat } \\
\text { Ketahanan } \\
\text { Pangan }\end{array}$} & $\begin{array}{c}\mathrm{Jml} \\
(\mathrm{n})\end{array}$ & $\%$ & $\begin{array}{c}\mathrm{Jml} \\
(\mathrm{n})\end{array}$ & $\%$ \\
\hline & \multicolumn{2}{|c|}{ BPS } & \multicolumn{2}{|c|}{$\begin{array}{c}\text { PPH dan UU } \\
\text { Pangan } \\
\end{array}$} \\
\hline Tahan pangan & 10 & 22,73 & 17 & 38,64 \\
\hline Kurang pangan & 7 & 15,91 & 12 & 27,27 \\
\hline Rentan pangan & 15 & 34,09 & 10 & 22,73 \\
\hline Rawan pangan & 12 & 27,27 & 5 & 11,36 \\
\hline Jumlah & 44 & 100,00 & 44 & 100,00 \\
\hline
\end{tabular}

\section{Analisis Tingkat Ketahanan Pangan}

Tingkat ketahanan pangan anggota lumbung berdasarkan kriteria PPH dan UU Pangan yang memperlihatkan bahwa lebih banyak rumah tangga yang tahan pangan yaitu sebanyak 38,64 persen. Rumah tangga mampu memenuhi kebutuhan di luar pangan dengan baik dan layak untuk anggota keluarga. Rumah tangga yang kurang pangan kategori ini juga memiliki pangsa pengeluaran rendah, yang pada dasarnya memiliki daya beli dan akses tinggi terhadap pangan. Hanya saja beberapa tidak dapat memanfaatkannya untuk memilih pangan dengan baik, sehingga tingkat kecukupan energi rumah tangga rendah. Sejalan dengan hasil penelitian Anggraini et al. (2014) bahwa rumah tangga kurang pangan kurang dapat mengalokasikan pendapatannya untuk belanja pangan dengan baik.

Berdasarkan kategori BPS, rumah tangga tahan pangan hanya sebanyak 22,73 persen padahal untuk tingkat kecukupan energi sebagian besar rumah tangga sudah cukup. Rumah tangga lebih banyak berada pada kriteria rentan pangan yaitu sebanyak 34,09 persen. Salah satu cara yang dapat dilakukan oleh rumah tangga untuk meningkatkan ketahanan pangannya adalah mencari pekerjaan tambahan, agar pendapatan meningkat dan dapat menurunkan pangsa pengeluaran pangan, serta tetap mempertahankan tingkat kecukupan energi yang cukup untuk rumah tangga.

\section{Faktor-faktor yang Memengaruhi Tingkat Ketahanan Pangan}

Berdasarkan hasil analisis, nilai Pseudo $\mathrm{R}^{2}$ sebesar 0,2384 yang menjelaskan bahwa sebesar 23,84 persen variasi peluang ketahanan pangan rumah tangga dapat dijelaskan oleh variasi variabel independen X1 sampai dengan X7 serta dummy.

Nilai probability LR statistik sebesar 0,0006 menjelaskan bahwa variabel pendidikan kepala keluarga, pendidikan istri, jumlah anggota keluarga, pendapatan rumah tangga, produksi padi, harga beras, harga minyak goreng, dan pekerjaan sampingan secara bersama-sama berpengaruh nyata terhadap peluang peningkatan rumah tangga anggota lumbung tahan pangan (Tabel 8).

Produksi padi berpengaruh positif dengan tingkat kepercayaan 95 persen yang berarti bahwa apabila terjadi peningkatan produksi padi, maka akan menyebabkan peluang rumah tangga untuk tahan pangan meningkat. 
Tabel 8. Analisis faktor yang memengaruhi ketahanan pangan rumah tangga anggota lumbung berdasarkan $\mathrm{PPH}$ dan UU Pangan

\begin{tabular}{|c|c|c|c|}
\hline Variabel & Koefisien & Z-statistic & Prob. \\
\hline Pendidikan KK & $-0,1004$ & $-0,4865$ & 0,6266 \\
\hline Pendidikan istri & $-0,1056$ & $-0,5118$ & 0,6088 \\
\hline Jumlah anggota & 0,2376 & 0,5951 & 0,5518 \\
\hline Pndptn rmh tangga & $-1,2374$ & $-0,1741$ & 0,8618 \\
\hline Produksi padi & $0,0008^{* *}$ & 2,4038 & 0,0162 \\
\hline Harga beras & $-0,0012^{*}$ & $-1,7963$ & 0,0725 \\
\hline Hrg mnyk goreng & 0,0003 & 0,7106 & 0,4773 \\
\hline Pekerj sampingan & $4,2797^{* * *}$ & 2,8826 & 0,0039 \\
\hline \multicolumn{4}{|c|}{ Limit Points } \\
\hline LIMIT_2:C(9) & $-5,8328$ & $-0,8382$ & 0,4019 \\
\hline LIMIT_3:C(10) & $-3,8960$ & $-0,5652$ & 0,5719 \\
\hline LIMIT_4:C(11) & $-2,1532$ & $-0,3136$ & 0,7538 \\
\hline Prob. (LR stat) & & & 0,0006 \\
\hline LR statistic & & & 27,3961 \\
\hline Pseudo-R2 & & & 0,2384 \\
\hline \multicolumn{4}{|l|}{ Keterar } \\
\hline $\begin{array}{ll}* & : \text { Tingkat kep } \\
* * & : \text { Tingkat kep } \\
* * * & : \text { Tingkat kep }\end{array}$ & $\begin{array}{l}\text { cayaan } 90 \text { persen } \\
\text { cayaan } 95 \text { persen } \\
\text { cayaan } 99 \text { persen }\end{array}$ & & \\
\hline
\end{tabular}

Peningkatan produksi padi akan menambah ketersediaan pangan pokok rumah tangga. Hasil tersebut sedikit berbeda dengan Rachman dan Ariani (2002) yang menyatakan tidak terpenuhinya ketahanan pangan di tingkat rumah tangga bukan disebabkan oleh tidak tersedianya pangan, namun lebih disebabkan oleh aspek distribusi dan daya beli.

Harga beras berpengaruh negatif dengan tingkat kepercayaan 90,00 persen yang berarti bahwa apabila terjadi peningkatan harga beras, maka akan menyebabkan peluang rumah tangga tahan pangan menjadi menurun. Harga beras yang mahal menyebabkan petani cenderung ingin menjual hasil produksi lebih banyak, sehingga menyebabkan pengurangan ketersediaan pangan pokok beras.

Pekerjaan sampingan merupakan usaha petani dalam meningkatkan pendapatan rumah tangganya selain dari usahatani padi. Jenis pekerjaan sampingan yang dilakukan responden bervariasi, ada yang menjadi pedagang, buruh bangunan hingga berusahatani budidaya bebek. Hasil analisis regresi menunjukkan bahwa pekerjaan sampingan berpengaruh positif pada tingkat kepercayaan 99,00 persen. Peluang peningkatan rumah tangga tahan pangan akan meningkat, apabila anggota lumbung memiliki pekerjaan sampingan.
Upaya Peningkatan Ketahanan Pangan Rumah Tangga Anggota Lumbung di Kecamatan Gading Rejo

Upaya peningkatan ketahanan pangan terwujud dalam program kerja pemerintah yang diharapkan dapat membantu meningkatkan pendapatan yaitu bantuan irigasi, peningkatan indeks pertanaman, dan sekolah lapang. Program ini diharapkan dapat meningkatkan produksi petani, sehingga pendapatan, kesejahteraan dan cadangan pangan petani meningkat. Program lainnya yang banyak diterima petani adalah bantuan beras sejahtera dan program keluarga harapan untuk menanggulangi adanya rawan pangan kronis, program cadangan pangan daerah, pengembangan lumbung pangan yang diberikan untuk mengatasi rawan pangan transien dan menstimulan petani agar mampu mengelola, mengembangkan kelembagaan lumbung serta mewujudkan fungsi lumbung yang sesungguhnya. Program untuk peningkatan gizi dilakukan dengan adanya penyuluhan gizi dan pangan oleh pemerintah dengan sosialisasi saat posyandu. Percepatan penganekaragaman pangan diwujudkan dengan kegiatan yang diikuti oleh ibu rumah tangga yaitu lomba menyusun menu yang beragam, bergizi, sehat dan aman.

Upaya yang dilakukan petani dalam mengatasi kekurangan pangan adalah dengan mengubah pola makan dengan merubah kualitas pangan yang dikonsumsi. Petani yang biasanya makan dengan lauk ayam harus mengurangi pengeluaran untuk memenuhi kebutuhan lainnya seperti mengganti ayam dengan ikan, ataupun tahu dan tempe. Mencari pekerjaan di luar usahatani juga dilakukan oleh petani untuk menambah pendapatan.

\section{KESIMPULAN}

Ketahanan pangan rumah tangga dianalisis berdasarkan kriteria BPS serta PPH dan Undangundang Pangan Tahun 2012. Rumah tangga tahan pangan menurut kategori BPS sebanyak 22,73 persen, kurang pangan 15,91 persen, rentan pangan 34,09 persen, dan rawan pangan 27,27 persen. Rumah tangga tahan pangan menurut kategori PPH dan UU Pangan sebanyak 45,45 persen, kurang pangan 27,27 persen, rentan pangan 15,91 persen, dan rawan pangan sebesar 11,36 persen. Faktorfaktor yang memengaruhi ketahanan pangan anggota lumbung adalah produksi padi, harga beras dan pekerjaan sampingan. Upaya peningkatan ketahanan pangan dilakukan dengan meningkatkan pendapatan dan gizi rumah tangga. Program yang diberikan untuk meningkatkan pendapatan antara 
lain irigasi bagi perkumpulan petani pemakai air, peningkatan indeks pertanaman, sekolah lapang. Program untuk peningkatan gizi dilakukan dengan adanya penyuluhan gizi dan pangan oleh pemerintah, percepatan penganekaragaman pangan, program keluarga harapan, pemberian beras sejahtera, pemberian cadangan pangan daerah, dan pengembangan lumbung pangan.

\section{DAFTAR PUSTAKA}

Anggraini M, Zakaria WA, dan Prasmatiwi FE. 2014. Analisis ketahanan pangan rumah tangga petani kopi di Kabupaten Lampung Barat. JIIA, 2 (2): 124-132. http://jurnal.fp. unila.ac.id/index.php/JIA/article/view/737.

[03 November 2017].

BPS [Badan Pusat Statistik] Kabupaten Pringsewu. 2017. Gading Rejo dalam Angka 2017. BPS Pringsewu. Pringsewu.

Darwanto DH dan Pranyoto A. 2006. Kebijakan dan Pengembangan Kelembagaan Pangan dalam Menunjang Ketahanan Pangan Nasional. Fakultas Pertanian Universitas Gadjah Mada. Jogjakarta.

DKP [Dinas Ketahanan Pangan] Kabupaten Pringsewu. 2017. Luas Panen dan Produksi Padi Sawah di Kabupten Pringsewu. DKP Kabupaten Pringsewu. Pringsewu.

Hernanda ENP, Indriani Y, dan Kalsum U. 2017. Pendapatan dan ketahanan pangan rumah tangga petani padi di desa rawan pangan. JIIA, 5 (3): 283-291. http://jurnal.fp.unila. ac.id/index.php/JIA/article/view/153 [03 November 2017].

Hernanda T, Indriani Y, dan Listiana I. 2013. Pendapatan usaha tani jagung dan ketahanan pangan rumah tangga petani di Kecamatan Simpang Kabupaten Ogan Komering Ulu (OKU) Selatan. JIIA, 1 (4): 311-318. http://jurnal.fp.unila.ac.id/index.php/JIA/arti cle/view/706 [03 November 2017].
Indriani Y. 2015. Gizi dan Pangan. Anugrah Utama Raharja. Bandar Lampung.

Mariyani S, Prasmatiwi FE, dan Adawiyah R. 2017. Ketersediaan pangan dan faktorfaktor yang memengaruhi ketersediaan pangan rumah tangga petani padi anggota lumbung pangan di Kecamatan Ambarawa Kabupaten Pringsewu. JIIA, 5 (3): 304-311. http://jurnal.fp.unila.ac.id/index.php/JIA/iss ue/view/159/showToc [05 Januari 2018].

Maxwell D Mc L, Klemeser MA M, Morris S, and Aliadeke C. 2000. Urban livelihoods and Food Nutition Security in Greater Accra, Ghana. IFPRI in collaborative with Noguchi Memorial for Medical Research and World Health Organization, Research Report No. 112. Washington, D.C.

Rachman HPS dan M Ariani. 2002. Ketahanan pangan, konsep, pengukuran dan strategi. Jurnal Forum Ekonomi Penelitian Agroekonomi (FAE), 20 (1): 12-24. https:// media.neliti.com/media/publications/61337ID-ketahanan-pangan-konsep-pengukurandan-s.pdf [9 September 2018].

Ramadhani F, Nurmayasari I, dan Prasmatiwi FE. 2018. Partisipasi petani pada lumbung pangan dalam meningkatkan ketersediaan pangan rumah tangga di Kecamatan Ambarawa, Kabupaten Pringsewu. JIIA, 6 (3): 361-367. http://jurnal.fp.unila.ac.id/ index.php/JIA/article/view/3052 Agustus 2019].

Sugesti MT, Abidin Z, dan Kalsum U. 2015. Analisis pendapatan dan pengeluaran rumah tangga petani padi Desa Sukajawa, Kecamatan Bumiratu Nuban, Kabupaten Lampung Tengah. JIIA, 3 (3): 251-259. http://jurnal.fp.unila.ac.id/index.php/JIA/arti cle/view/1049/954. [3 November 2017].

Sugiarto D, Siagian LS, Sunaryanto, dan Oetomo DS. 2003. Teknik Sampling. PT Gramedia Pustaka Utama. Jakarta. 